\title{
Treatment outcome monitoring of pulmonary tuberculosis cases notified in France in 2009
}

D Antoine (d.antoine@invs.sante.fr) ${ }^{1}$, D Che $^{1}$

1. Institut de Veille Sanitaire, Saint Maurice cedex, France

Citation style for this article:

Antoine D, Che D. Treatment outcome monitoring of pulmonary tuberculosis cases notified in France in 2009. Euro Surveill. 2013;18(12):pii=20434. Available online: http://www.eurosurveillance.org/ViewArticle.aspx?Articleld=20434

The proportion of patients considered to be cured is a key indicator to assess national tuberculosis (TB) control. In France, TB treatment outcome monitoring was implemented in 2007. This article presents national results on treatment outcome among patients with pulmonary TB reported in France in 2009 and explores determinants of potentially unfavourable outcome. Information on treatment outcome was reported for $63 \%$ of eligible pulmonary cases of whom $70 \%$ had a successful outcome. In a multivariate analysis, potentially unfavourable outcome (17\%), compared to treatment success, was significantly associated with being male, born abroad and having lived in France for less than 10 years, being in congregate settings when treatment was initiated, or having a previous history of anti-TB treatment. Enhanced awareness of treatment outcome monitoring is essential to improve the coverage and the quality of information. Earlier diagnosis and improved management of the disease in the elderly may reduce death due to TB. The high proportion of potentially unfavourable outcomes should be further investigated as they may require additional vigilance and/or actions in term of efforts of TB control in some population groups.

\section{Introduction}

France is considered to be a low tuberculosis (TB) incidence country with 8.1 TB cases notified per 100,000 population in $2010(n=5,187)$, but the disease tends to be concentrated in urban settings and in certain population groups [1]. Early detection and prompt management of patients by adequate and complete treatment remain the main tools of $T B$ control and form the main objectives of the French national TB control programme launched in 2007 [2]. Appropriate treatment can cure the patient, limit the spread of the disease in the community by reducing the infectious period of the patient, and avoid the development of drug resistance. The proportion of cases considered to be cured is therefore a key indicator in the evaluation of national TB programmes. In 1995, the World Health Organization (WHO) set a target of $85 \%$ treatment success among new sputum smear-positive cases [3]. Following recommendations for the standardisation of TB treatment outcome in Europe published in 1998 [4], national systems for routine treatment outcome monitoring was gradually developed in all European countries. In France, following a pilot study in 2005 and some local initiatives, especially in Paris and its suburbs in the mid-1990s [5], a national system for treatment outcome monitoring in TB patients was implemented in 2007 as part of the mandatory TB notification system. This article presents the national results of treatment outcome monitoring among patients with pulmonary TB reported in France in 2009 and explores determinants of potentially unfavourable outcome.

\section{Methods}

\section{Data sources}

In France, TB is a mandatorily notifiable disease. Each physician or microbiologist diagnosing TB should report the case to their corresponding Regional Health Agency (Agence Régionale de Santé, ARS) using a standardised paper notification form. Twelve months after the start of treatment or after the date of diagnosis, the ARS requests information from the notifying physician on treatment outcome of the patient, through a paper form sent directly or via the district TB control centre (Centre de lutte antituberculeuse, CLAT). This form contains the originally collected patient data, i.e. date of notification, date of birth, first name, initial of last name and postcode of residence, and allows the physician to add the outcome. Data are anonymised and transmitted electronically to the French Institute for Public Health Surveillance (Institut de Veille Sanitaire; InVS) every year.

The cohort eligible for our analysis included patients with pulmonary TB, with or without extra-pulmonary localisation, notified in 2009 in France (including overseas districts). Overseas districts are always included in national surveillance results. Among hundred French districts, four are overseas. Cases notified in these overseas districts represent annually around $2-3 \%$ of all cases notified in France. We excluded patients who after notification were found not to have TB (atypical 
TABLE 1

Treatment outcome categories used for surveillance, France, 2009

\begin{tabular}{|c|c|}
\hline $\begin{array}{l}\text { Treatment } \\
\text { outcome category }\end{array}$ & Definitions \\
\hline $\begin{array}{l}\text { 1. Treatment } \\
\text { success } \\
\text { (treatment } \\
\text { completed) }\end{array}$ & $\begin{array}{l}\text { Patient is declared cured by a clinician, } \\
\text { with or without documented bacteriological } \\
\text { conversion, and has taken at least } 80 \% \text { of } \\
\text { the standard anti-TB treatment }\end{array}$ \\
\hline \multirow{4}{*}{ 2. Death } & $\begin{array}{l}\text { Death of the patient during treatment, } \\
\text { including }\end{array}$ \\
\hline & death from TB \\
\hline & death from another cause \\
\hline & unknown link between death and TB \\
\hline \multirow{3}{*}{$\begin{array}{l}\text { 3. Treatment } \\
\text { stopped }\end{array}$} & Treatment has been stopped because of \\
\hline & other diagnosis \\
\hline & other reason \\
\hline \multirow{4}{*}{$\begin{array}{l}\text { 4. Still on } \\
\text { treatment at } \\
12 \text { months }\end{array}$} & $\begin{array}{l}\text { Patient is still on treatment at } 12 \text { months, } \\
\text { for reasons including }\end{array}$ \\
\hline & $\begin{array}{l}\text { initially planned treatment } \\
\text { for more than } 12 \text { months } \\
\text { (e.g. because of drug resistance) }\end{array}$ \\
\hline & $\begin{array}{l}\text { treatment interruption for more } \\
\text { than two months }\end{array}$ \\
\hline & $\begin{array}{l}\text { treatment change for } \\
\text { (one or several situations) } \\
\text { - initial or acquired drug resistance } \\
\text { - adverse reactions to treatment } \\
\text { - failure of the initial treatment } \\
\text { (insufficient clinicalresponse or non- } \\
\text { negativity of bacteriological results) }\end{array}$ \\
\hline 5. Transfer out & $\begin{array}{l}\text { Patient has been transferred to another } \\
\text { hospital or to another physician than the } \\
\text { notifying person }\end{array}$ \\
\hline $\begin{array}{l}\text { 6. Lost to } \\
\text { follow-up }\end{array}$ & $\begin{array}{l}\text { Patient was lost to follow-up during } \\
\text { treatment and is still lost to follow-up } 12 \\
\text { months after starting treatment }\end{array}$ \\
\hline $\begin{array}{l}\text { 7. Information } \\
\text { unknown }\end{array}$ & \\
\hline
\end{tabular}

TB: tuberculosis.

mycobacteria, cancer etc.) and patients with a postmortem diagnosis of TB.

\section{Tuberculosis case definition}

TB cases to be notified include patients with clinical and/or radiological signs compatible with TB and with a clinician decision to treat the patient with a standard anti-TB treatment, whether cases are confirmed by a positive culture for Mycobacterium tuberculosis complex or not.

Following the European definition for surveillance [6], pulmonary TB includes TB affecting lung parenchyma, tracheobronchial tree or larynx.

\section{Treatment outcome monitoring}

The principles and methods of TB surveillance implemented in France are based on European recommendations [4] adapted to the French context. In the 1998 European recommendations, successful outcomes included two categories: 'treatment completed' (documented treatment completion but no documented bacteriological conversion) and 'cured' (documented bacteriological conversion during the continuation phase) [4]. In France, as in some other European countries $[7,8]$ the category 'treatment completion', indicating a treatment success, was defined as 'documented treatment completion with or without documented bacteriological conversion' and included patients classified as 'cured'.

Information collected on outcome (Table 1) is about the situation of the patients whose TB was notified within 12 months following the start of treatment or the date of diagnosis.

Patients classified as 'defaulter' in the WHO definitions [3] (i.e. patients lost to follow-up, still on treatment at 12 months due to treatment interruption of more than two months, and treatment stop), and patients transferred out to another clinician and service, were considered, in this study, as having a potentially unfavourable outcome [9]. These outcomes may indicate a higher risk of relapse or anti-TB drug resistance.

Initial TB notification and treatment outcome monitoring forms are available on the InVS website at the following link: https://www.formulaires.modernisation. gouv.fr/gf/cerfa_13351.do

\section{Statistical analysis}

Data analysis was performed on eligible cases for whom information on treatment outcome was available. Unless otherwise indicated in the text, the denominator for calculated percentages was the number of cases with known information. Data analysis was performed with Epi Info software (version 3.3.2 TM, Centers for Disease Control, United States) and Stata 11 (Stata Corporation Texas, United States). Data comparisons were made using the chi-square test or Fisher's exact test, with a $\mathrm{p}$ value of less than $0.05(5 \%)$ considered statistically significant.

Characteristics of patients with potentially unfavourable outcome were compared with patients with treatment success, using multivariable logistic regression. The variables sex and age group were systematically included in the multivariable analysis as well as variables with a $p$ value of less than 0.2 in the bivariate analysis. Possible interactions in the model were investigated. Goodness of fit was assessed by the Hosmer and Lemeshow test.

\section{Results}

Files transmitted by ARS included reports of 3,789 pulmonary TB cases notified in 2009, accounting for around $70 \%$ of all notified TB cases. 


\section{FIGURE 1}

Algorithm for inclusion of cases in the analysis on treatment outcome of pulmonary tuberculosis cases notified in France, 2009 ( $n=3,789)$

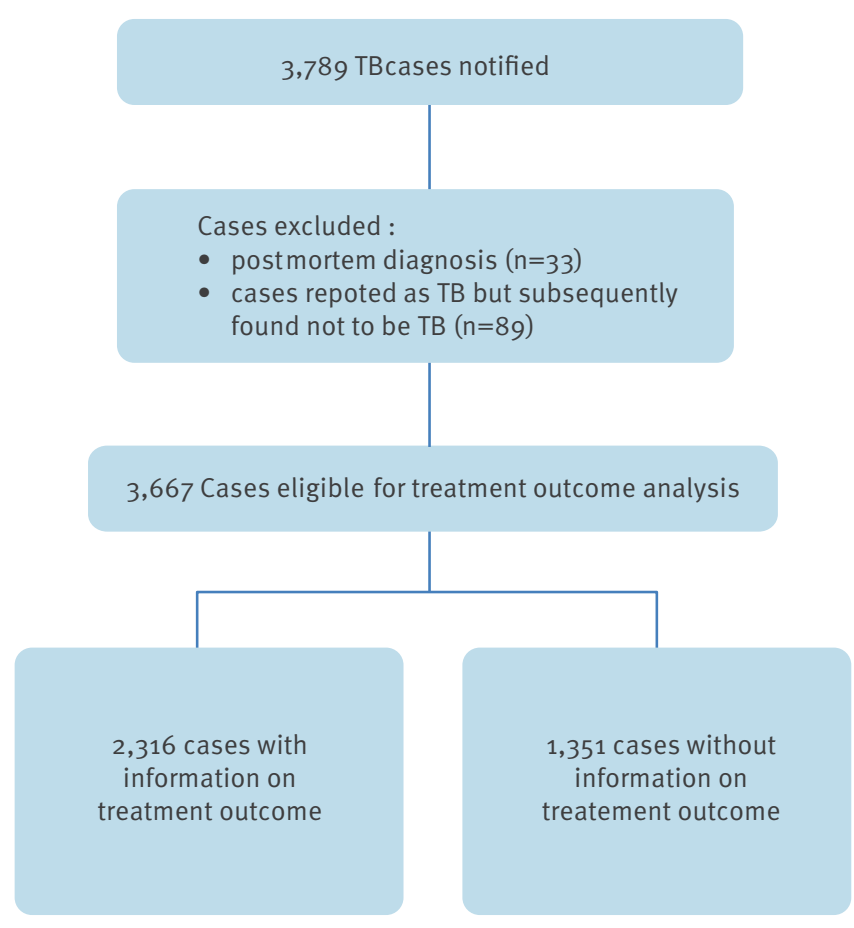

TB: tuberculosis.

Of these 3,789 pulmonary cases, 122 cases were excluded from the analysis: 33 cases because they were diagnosed post-mortem, and 89 cases because they were initially reported as TB disease but subsequently found not to have TB. The remaining 3,667 pulmonary cases reported in 2009 were therefore eligible for the analysis of treatment outcomes (Figure 1).

Information on outcomes of treatment was completed for 2,316 patients with pulmonary TB reported in 2009 (63\% of eligible cases: $2,316 / 3,667$ ) of whom $96.5 \%$ lived in metropolitan France and $3.5 \%$ in overseas territories. Information on treatment outcome was lacking for $37 \%$ of the patients $(1,351 / 3,667)$ either because the notifying person did not receive the form (insufficient contact details, career change, treatment outcome monitoring not implemented by the district) or because the clinician did not retrieve information on the patient.

\section{Case characteristics}

Among the 2,316 cases notified in 2009 with reported information on treatment outcome, $61 \%$ were male. The median age was 43 years (interquartile range: $29-64$ years). Information on country of birth was completed for 2,169 (94\%) cases, of whom $51 \%(1,106 / 2,169)$ were born in France and 49\% $(1,063 / 2,169)$ were born abroad.

Patients living in congregate settings at the time of treatment start represented $14 \%(315 / 2,316)$ of the cases. Two thirds (66\%) of these patients were living in sheltered housing or in residential centres, $21 \%$ in nursing homes for the elderly, $11 \%$ were in prison, and for $3 \%$ the type of congregate setting was not reported.

Information on previous history of anti-TB treatment was available for $65 \%(1,503 / 2,316)$ of the pulmonary cases included in the study. Of these cases, $14 \%$ $(204 / 1,503)$ had a previous history of treatment and $86 \%(1,299 / 1,503)$ were new cases.

Among pulmonary cases with known information, $53 \%$ $(1,145 / 2,179)$ were sputum smear-positive. Culture result was reported for $61 \%(1,419 / 2,316)$ of cases, of whom $98 \%(1,417 / 1,419)$ were positive. The proportion of multidrug-resistant cases (resistant to at least isoniazid and rifampicin) was $2.3 \%$ among cases with a drug susceptibility testing result reported in the notification form $(n=812)$.

Distribution of cases according to sex, age, birthplace, history of TB and multidrug resistance were similar for cases with and cases without information on treatment outcome.

\section{The situation of the patients} regarding treatment outcome

The proportion of treatment success was $70 \%$ $(1,623 / 2,316)$ among patients with pulmonary TB reported in 2009 for whom information of treatment outcome was available (Table 2). The proportion of treatment success was significantly higher in cases with a negative sputum smear result than in those with a positive sputum smear result ( $73 \%$ versus $67 \%$; p $<0.001)$ and was $71.2 \%(467 / 652)$ in the cohort of new sputum smear-positive cases.

Thirty per cent of eligible pulmonary TB cases notified in France in 2009 and with available information on treatment outcome $(693 / 2,316)$ did not complete the treatment at 12 months. Of these:

- 222 (32\%) patients died during the treatment; $28 \%$ of the deaths were due to TB, $44 \%$ were not due to TB, and for $28 \%$ the link between death and TB was unknown;

- $220(32 \%)$ patients were lost to follow-up during the treatment and remained so 12 months after treatment start;

- 119 (17\%) patients were transferred out to another service or physician;

- $100(14 \%)$ patients were still on treatment at 12 months; this was due to initially planned treatment of more than 12 months for 43 patients, to treatment modification (anti TB drug resistance, adverse reactions and treatment failure) for 34 patients, and to 
treatment interruption of more than two months for 23 cases.

- 32 (5\%) patients had stopped their treatment.

Being lost to follow-up or still on treatment at 12 months due to treatment interruption of more than two months, and treatment stop and being transferred out were considered as a potentially unfavourable treatment outcome and were reported for a total of 394 patients (17\%).

The proportion of patients with successful treatment decreased with age, while the proportion of deaths increased (Figure 2). Thus, in persons younger than 25 years, the proportion of pulmonary cases with treatment success was $76 \%(273 / 357)$ and the proportion of deaths was $1.1 \%$ (4/357), while they were respectively $57 \%(324 / 567)$ and $28 \%(159 / 567)$ among those aged 65 years and older ( $p<0.001)$. The proportion of patients with potentially unfavourable outcome of treatment was more than $10 \%$ in all age groups and peaked at $22 \%$ in young adults aged 15 to 24 years ( $57 / 264)$.

\section{Determinants of potentially}

\section{unfavourable treatment outcome}

The multivariable analysis (Table 3 ) identified the following factors as significantly associated with potentially unfavourable outcome compared to treatment success:

being male (odds ratio (OR): 1.6 ; $95 \%$ confidence interval (Cl): 1.1 to 2.1 ); being born abroad and having lived in France less than 10 years before the start of treatment (OR: $1.6 ; 95 \% \mathrm{Cl}$ : 1.1 to 2.4 for entry less than five years, and OR: 1.8 ; $95 \% \mathrm{Cl}: 1.1$ to 3.0 for entry five to nine years before TB diagnosis);

living in congregate settings, including sheltered housing, residential centres, prison, or nursing homes for elderly persons, at the time of the start of treatment (OR: $2.5 ; 95 \% \mathrm{Cl}: 1.7$ to 3.7 );

having a previous history of anti-TB treatment (OR: 2.0; $95 \% \mathrm{Cl}: 1.2$ to 3.1 ).

No significant interaction was found in the final model.

\section{Discussion}

Treatment outcome monitoring in France among pulmonary cases reported in 2009 resulted in information provided for $63 \%$ of the cases. Of those, $70 \%$ had completed treatment (with or without bacteriological conversion) within one year.

Some limitations should be taken into account when interpreting the results presented. A large proportion of reported cases were missing information on treatment outcome $(37 \%)$, although this proportion has been decreasing since the implementation of treatment outcome monitoring ( $45 \%$ in $2007,40 \%$ in 2008 ) [10]. Information is difficult to obtain, especially when, as in France, data are collected through surveys rather than registered, and when several different professionals and institutions may be involved in the management

\section{TABLE 2}

Pulmonary tuberculosis cases, by treatment outcome, France, 2009 (n=2,316)

Pulmonary cases

Situation at 12 months after starting treatment or being notified

Number of cases

\begin{tabular}{|c|c|c|}
\hline $\begin{array}{l}\text { Treatment success } \\
\text { (with or without bacteriological conversion) }\end{array}$ & 1,623 & 70.1 \\
\hline Death & 222 & 9.6 \\
\hline - due to TB & 62 & 2.7 \\
\hline - not due to TB & 97 & 4.2 \\
\hline - link TB and death not known & 63 & 2.7 \\
\hline Treatment stopped & 32 & 1.4 \\
\hline Still on treatment due to & 100 & $4 \cdot 3$ \\
\hline - initially planned treatment >12 months, & 43 & 1.8 \\
\hline $\begin{array}{l}\text { - treatment modification } \\
\text { (adverse reaction, anti-TB drug resistance, treatment failure) }\end{array}$ & 30 & 1.3 \\
\hline - treatment interruption & 23 & 1.0 \\
\hline - reasons not provided & 4 & 0.2 \\
\hline Transfer out & 119 & 5.1 \\
\hline Lost to follow-up & 220 & $9 \cdot 5$ \\
\hline Total & 2,316 & 100.0 \\
\hline
\end{tabular}

TB: tuberculosis. 


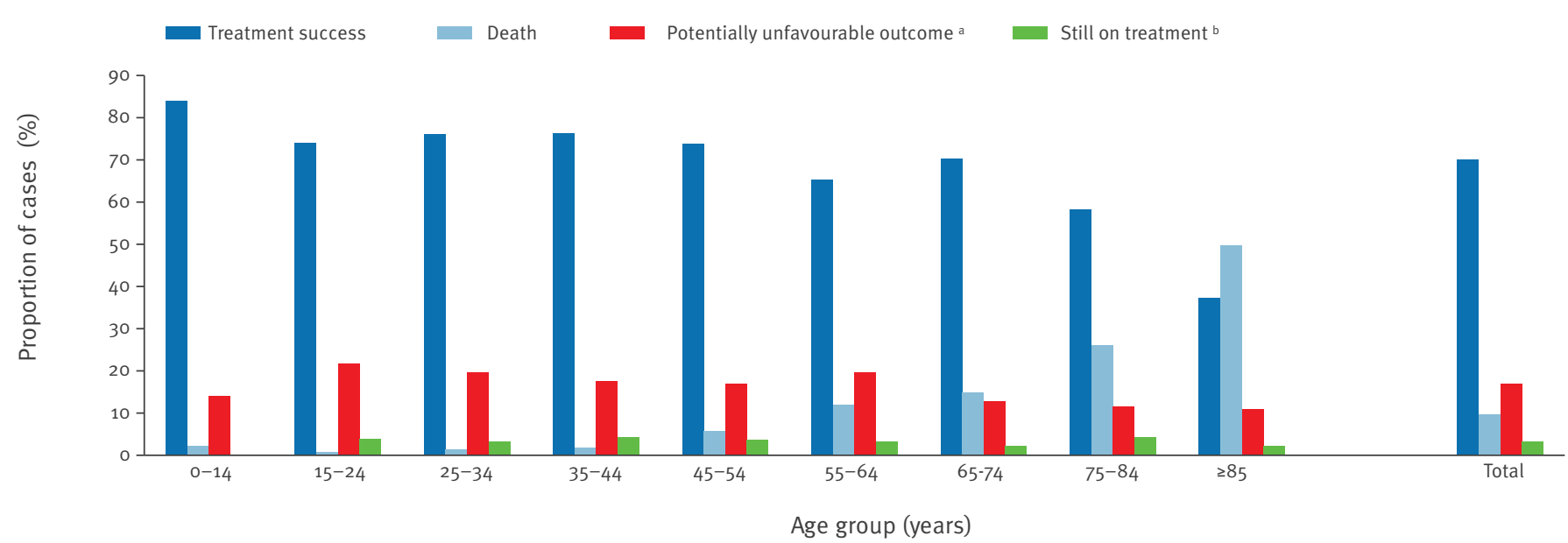

a Potentially unfavourable outcomes: treatment stopped, still on treatment due to treatment interruption (for more than two months), lost to follow up, transfer out.

b Still on treatment including initially planned treatment for $>12$ months, treatment modification (adverse reaction, anti-tuberculosis drug resistance, treatment failure).

and the follow-up of one TB patient. The form used to complete information on treatment outcome is sent to the notifying physician who may not be the one following the patient during the treatment. In addition, national regulations on confidentiality and data protection limit the information available to retrieve the patient data. Efforts are therefore needed to facilitate the collection of information and to improve awareness of health professionals in order to increase the proportion of cases with information on the outcome of treatment.

Most socio-demographic and clinical data for cases with information on treatment outcome were similar to those for cases without information. However, other factors that are not collected as part of the notification, such as co-morbidities, drug or alcohol consumption, but probably also living and housing conditions, could have an impact on the outcome of treatment [11-14]. From the available information, it is not possible to determine whether cases without information on treatment outcome would be more, equally or less likely to complete their treatment than those for whom the outcome of treatment is known. In addition the high proportion of missing information for previous history of anti TB treatment (35\%) and culture results (39\%) should be taken into account. Therefore caution is needed when extrapolating the results presented in this article to all TB patients.
Among the patients with pulmonary TB reported in 2009 for whom the outcome of treatment was provided, $70 \%(1,623 / 2,316)$ had a successful outcome within 12 months after its start. The proportion of treatment success was significantly higher in patients with sputum smear-negative TB compared to those with sputum smear-positive TB (73\% versus 67\%; p<0.001). The lower proportion of treatment success in patients who are more likely to transmit the disease should be further investigated.

The proportion patients with successful treatment was $71 \%(467 / 652)$ in the cohort of new sputum smear-positive cases and was well below the WHO target of $85 \%$ favourable treatment outcomes. The European recommendations indicated that it may be difficult to reach a death rate lower than $5 \%$ and that the rate of unsatisfactory outcome should not exceed 10\% [4].

In France, the proportion of deaths (due or not due to TB) was higher than $5 \%$ with $9.6 \%$ among pulmonary TB cases. This was mainly due to the impact of TB in the elderly (65 years and older) who represented $26 \%$ (974/3,789) of patients with pulmonary TB initially reported in 2009 and $25 \%$ of patients with information on treatment outcome $(567 / 2,316)$. Among those who died within the 12 months following initiation of treatment, $72 \%$ were 65 years and older (159/222). This proportion is comparable with other low-incidence countries [15]. 


\section{TABLE 3}

Determinants of potentially unfavourable outcome versus treatment success among pulmonary tuberculosis cases reported in France, $2009\left(\mathrm{n}=2,017^{\mathrm{a}}\right)$

\begin{tabular}{|c|c|c|c|c|c|c|c|c|}
\hline \multirow{3}{*}{$\begin{array}{l}\text { Case characteristic (at the time of TB } \\
\text { notification) }\end{array}$} & \multicolumn{2}{|c|}{ Number of cases } & \multirow{2}{*}{\multicolumn{3}{|c|}{$\begin{array}{l}\text { Univariable analysis for } \\
\text { potentially unfavourable outcome } \\
\text { vs. treatment success }\end{array}$}} & \multirow{2}{*}{\multicolumn{3}{|c|}{$\begin{array}{c}\text { Multivariable analysis for } \\
\text { potentially unfavourable outcome } \\
\text { vs. treatment success }\end{array}$}} \\
\hline & \multirow{2}{*}{$\begin{array}{l}\text { Potentially } \\
\text { unfavourable } \\
\text { outcome }^{b}\end{array}$} & \multirow{2}{*}{$\begin{array}{l}\text { Treatment } \\
\text { success }\end{array}$} & & & & & & \\
\hline & & & OR & {$[95 \% \mathrm{Cl}]$} & p Value & OR & [95\% Cl] & p Value \\
\hline Total & 394 & 1,623 & - & - & - & - & - & - \\
\hline \multicolumn{9}{|l|}{$\operatorname{Sex}(n=2,010)$} \\
\hline Female & 117 & 661 & \multicolumn{3}{|c|}{ Ref } & \multicolumn{3}{|c|}{ Ref } \\
\hline Male & 277 & 955 & 1.6 & {$[1.3-2.1]$} & $p<0.001$ & 1.6 & {$[1.1-2.1]$} & 0.005 \\
\hline \multicolumn{5}{|l|}{ Age $(n=2,016)$} & $p=0.573$ & & & $p=0.537$ \\
\hline $0-24$ years & 70 & 273 & \multicolumn{3}{|c|}{ Ref } & \multicolumn{3}{|c|}{ Ref } \\
\hline $25-44$ years & 158 & 645 & 0.9 & [0.7-1.3] & 0.776 & 0.9 & [0.6-1.4] & 0.790 \\
\hline $45-64$ years & 99 & 380 & 1.0 & {$[0.7-1.4]$} & 0.928 & 0.9 & [0.6-1.5] & 0.853 \\
\hline$\geq 65$ years & 67 & 324 & 0.8 & {$[0.6-1.2]$} & 0.257 & 0.7 & {$[0.4-1.2]$} & 0.190 \\
\hline \multicolumn{5}{|c|}{ Place of birth and time since arriving in France $(n=1,598)$} & p<0.001 & & & $p=0.029$ \\
\hline Born in France & 138 & 780 & \multicolumn{3}{|c|}{ Ref } & \multicolumn{3}{|c|}{ Ref } \\
\hline $\begin{array}{l}\text { Born abroad and arrived in France } \\
\ll 5 \text { years before diagnosis }\end{array}$ & 84 & 236 & 2.0 & {$[1.5-2.7]$} & $<0.001$ & 1.6 & {$[1.1-2.4]$} & 0.014 \\
\hline $\begin{array}{l}\text { Born abroad and arrived in France } \\
5-9 \text { years before diagnosis }\end{array}$ & 32 & 104 & 1.7 & {$[1.1-2.7]$} & 0.012 & 1.8 & {$[1.1-3.0]$} & 0.020 \\
\hline $\begin{array}{l}\text { Born abroad and arrived in France } \\
\text { >9 years before diagnosis }\end{array}$ & 37 & 187 & 1.1 & {$[0.8-1.7]$} & 0.580 & 1.1 & {$[0.7-1.7]$} & 0.763 \\
\hline \multicolumn{9}{|l|}{ Homeless $(n=1,771)$} \\
\hline No & 316 & 1,372 & \multicolumn{3}{|c|}{ Ref } & \multicolumn{3}{|c|}{ Ref } \\
\hline Yes & 29 & 54 & 2.3 & {$[1.4-3.8]$} & $p<0.001$ & 1.2 & [0.6-2.3] & 0.558 \\
\hline \multicolumn{9}{|l|}{ Being in congregate settings $(n=1,809)$} \\
\hline No & 266 & 1,284 & \multicolumn{3}{|c|}{ Ref } & \multicolumn{3}{|c|}{ Ref } \\
\hline Yes & 91 & 168 & 2.6 & {$[1.9-3.5]$} & $p<0.001$ & 2.5 & {$[1.7-3.7]$} & $p<0.001$ \\
\hline \multicolumn{5}{|l|}{ Previous anti-TB treatment $(\mathrm{n}=2,017)$} & $p=0.005$ & & & $p=0.015$ \\
\hline No & 206 & 960 & \multicolumn{3}{|c|}{ Ref } & \multicolumn{3}{|c|}{ Ref } \\
\hline Yes & 47 & 122 & 1.8 & {$[1.2-2.6]$} & 0.002 & 2.0 & {$[1.2-3.1]$} & 0.004 \\
\hline $\begin{array}{l}\text { Unknown history of previous } \\
\text { anti-TB treatment }\end{array}$ & 141 & 541 & 1.2 & {$[0.9-1.5]$} & 0.110 & 1.0 & {$[0,7-1,7]$} & 0.823 \\
\hline \multicolumn{9}{|l|}{ Sputum smear result $(n=1,988)$} \\
\hline Negative & 178 & 840 & \multicolumn{3}{|c|}{ Ref } & \multicolumn{3}{|c|}{ Ref } \\
\hline Positive & 206 & 764 & 1.3 & {$[1.1-1.6]$} & 0.008 & 1.3 & {$[0.9-1.7]$} & 0.103 \\
\hline \multicolumn{5}{|c|}{ Drug susceptibility results for INH and RMP $(n=2,017)$} & $p=0.476$ & & & \\
\hline $\begin{array}{l}\text { TB sensitive to INH and RMP } \\
\text { (not multidrug-resistant) }\end{array}$ & 142 & 560 & & Ref & & & - & \\
\hline Multidrug-resistant & 3 & 6 & 1.9 & {$[0.5-7.9]$} & 0.333 & - & - & - \\
\hline Drug susceptibility result not known & 249 & 1,057 & 0.9 & {$[0.7-1.2]$} & 0.531 & - & - & - \\
\hline
\end{tabular}

Differences between totals (394 and 1,623) and totals by case characteristic are due to missing information.

$\mathrm{Cl}$ : confidence interval; INH: isoniazid; OR: odds ratio; RMP: rifampicin; TB: tuberculosis.

a Including patients with potentially unfavourable outcome or with treatment success. Excluding deaths ( $\mathrm{n}=222$ ), patients still on treatment due to initially planned treatment of $>12$ months $(n=43)$, treatment modification $(n=30)$ or unavailability of reasons for being still on treatment $(n=4)$.

b Including treatment stop, still on treatment due to treatment interruption, lost to follow-up and transfer out. 
Deaths unrelated to TB should not be considered as unfavourable treatment outcome in terms of TB control. Similarly, a patient still on treatment at 12 months because the initial treatment was planned to be longer than one year or changed due to side effects or an insufficient clinical response to the treatment, will not always have an unfavourable final outcome. This would be especially true in countries with low TB incidence such as France, where financial, technical and medical resources make it likely that the final outcome of most patients still in treatment at 12 months will be favourable [16].

However, the proportion of potentially unfavourable outcomes was $17 \%$ in patients with pulmonary TB notified in 2009. This included those lost to follow-up, those still on treatment at 12 months due to treatment interruption of more than two months, treatment stop or transfer out to another clinician and service.

Patients lost to follow-up represented $9.5 \%$ of the cases with information on treatment outcome. According to information provided by some clinicians, the category 'lost to follow-up' may not only be used to qualify the status of the patient, but also to indicate that the records of the patients were lost. However, both situations are unfavourable in terms of TB control.

The proportion of $5.1 \%$ of patients transferred out may be due in part to the organisation of healthcare in France, where several health professionals or services may be involved in the diagnosis and follow-up of the patients until the end of the treatment [17]. In addition, population mobility within France but also internationally may impact on the proportion of patients transferred out. Therefore, improving international collaboration to ensure adequate follow-up of patients moving abroad as well as measures to ensure continuity of the treatment and improve the exchange of information between services in France are essential [18]. The situation of the patient may not be unfavourable, but missing information can make it impossible to draw any conclusions about whether or not the treatment was successful.

Male patients who were born abroad and had lived in France for less than 10 years before the start of treatment, who were living in congregate settings at the time of the start of treatment or who had a previous history of anti-TB treatment, were at risk for an unfavourable treatment outcome. Despite some differences in methods and cohort definition, these results are consistent with other studies performed in western European countries [11,14].

It was impossible, due to small numbers of the study population, to include the precise type of congregate setting in the model. The results should therefore be interpreted with caution. However, a large proportion of the part of the study population living in congregate settings was housed in shelters, residential centres or prisons, where the mobility is usually high. Possible discontinuation of treatment for released prisoners has been described in other studies in Europe [19-21]. Disruption of treatment may also occur when a patient is leaving a sheltered housing or residential house before the end of the treatment. Therefore strengthening communication and coordination between the healthcare systems in and outside these institutions seems essential.

Despite the limitations owing to the large proportion of cases without information, the fact that $67 \%$ of sputum smear-positive cases and $70 \%$ of all pulmonary cases had completed treatment, will be a basis for trends analyses in the coming years.

In some other European countries with a similar epidemiological situation such as Germany and the United Kingdom, the proportion of treatment completion was lower than $75 \%$ in the first years of national treatment outcome monitoring and has increased after that $[6,22]$.

In France, TB incidence has been decreasing for a few decades, especially in persons born in France, and the number and proportion of paediatric TB cases as well as the proportion of resistance among new cases have been stable and low [1]. This situation is encouraging in terms of TB control, but contrasts with the results of treatment outcome monitoring. The results presented here demonstrate the need to improve the proportion of patients with reported information and the quality of collected information. Enhanced awareness of the value of treatment outcome monitoring is therefore essential. Earlier diagnosis and improved management of the disease in the elderly may reduce death due to TB [23]. The high proportion of potentially unfavourable outcomes should be closely monitored as they may indicate particular population groups in which vigilance and/or TB control measures need to be improved, including persons born abroad and recently arrived in France, persons living in congregate settings at the start of treatment and patients with a previous history of anti-TB treatment.

\section{Acknowledgements}

We would like to acknowledge the health professionals, the staff of Regional Health Authorities (ARS) and the tuberculosis control centres (Clat) for their contributions to data collection and to improvement of surveillance of tuberculosis in France.

\section{References}

1. Antoine $D$, Che D. Les cas de tuberculose maladie déclarés en France en 2010. [Cases of tuberculosis notified in France in 2010]. Bull Epidemiol Hebd. 2012;24-25:285-7. French. Available from: http://www.invs.sante.fr/content/ download/38173/181054/version/3/file/beh_24_25_2012.pdf

2. Lévy-Bruhl D, Paty MC, Antoine D, Bessette D. Recent changes in tuberculosis control and BCG vaccination policy in France. 
Euro Surveill. 2007;12(37):pii=3268. Available from: http:// www.eurosurveillance.org/ViewArticle.aspx?Articleld $=3268$

3. World Health Organization (WHO). Treatment of tuberculosis: Guidelines for National Programmes. 4th ed. Geneva: WHO; 2010. Report No.: WHO/HTM/TB/2009.420. Available from: http://whqlibdoc.who.int/publications/2010/9789241547833_ eng.pdf

4. Veen J, Raviglione M, Rieder HL, Migliori GB, Graf P, Grzemska $M$, et al. Standardized tuberculosis treatment outcome monitoring in Europe. Recommendations of a Working Group of the World Health Organization (WHO) and the European Region of the International Union Against Tuberculosis and Lung Disease (IUATLD) for uniform reporting by cohort analysis of treatment outcome in tuberculosis patients. Eur Respir J. 1998;12(2):505-10. http://dx.doi.org/10.1183/09031936.98.120 20505. PMid:9727811.

5. Farge D, Porcher R, Antoun F, Fain O, Keshtmand H, Rocher G, et al. Tuberculosis in European cities: establishment of a patient monitoring system over 10 years in Paris, France. Int J Tuberc Lung Dis. 2007;11(9):992-8. PMid:17705977.

6. European Centre for Disease Prevention and Control (ECDC)/ WHO Regional Office for Europe. Tuberculosis surveillance and monitoring in Europe 2012. Stockholm: ECDC; 2012. Available from: http://ecdc.europa.eu/en/publications/ publications/1203-annual-tb-report.pdf

7. Antoine D, French CE, Jones J, Watson JM. Tuberculosis treatment outcome monitoring in England, Wales and Northern Ireland for cases reported in 2001. J Epidemiol Community Health. 2007;61(4):302-7. http://dx.doi.org/10.1136/ jech.2005.044404. PMid:17372289 PMCid:2652938.

8. Falzon D, Scholten J, Infuso A. Tuberculosis outcome monitoring--is it time to update European recommendations? Euro Surveill. 2006;11(3): pii=608. Available from: http://www. eurosurveillance.org/ViewArticle.aspx?Articleld $=608$

9. Helbling P, Medinger C, Altpeter E, Raeber PA, Beeli D, Zellweger JP. Outcome of treatment of pulmonary tuberculosis in Switzerland in 1996. Swiss Med Wkly. 2002;132(35-36):517 22. PMid:12506334.

10. Antoine D, Che D. Les issues de traitement des cas de tuberculose déclarés en France en 2008. [Treatment outcome of tuberculosis cases notified in France in 2008]. Bull Epidemiol Hebd. 2011;(32):345-8. French. Available from: http://opac.invs.sante.fr/doc_num.php?explnum_id=7348

11. Caylà JA, Caminero JA, Rey R, Lara N, Vallés X, Galdós-Tangüis $\mathrm{H}$, et al. Current status of treatment completion and fatality among tuberculosis patients in Spain. Int J Tuberc Lung Dis. 2004;8(4):458-64. PMid:15141739.

12. Valin N, Hejblum G, Borget I, Mallet HP, Antoun F, Che D, et al. Management and treatment outcomes of tuberculous patients, eastern Paris, France, 2004. Int J Tuberc Lung Dis. 2009;13(7):881-7. PMid:19555539.

13. Diel R, Niemann S. Outcome of tuberculosis treatment in Hamburg: a survey, 1997-2001. Int J Tuberc Lung Dis. 2003;7(2):124-31. PMid:12588012.

14. Borgdorff MW, Veen J, Kalisvaart N. Broekmans JF, Nagelkerke NJ. Defaulting from tuberculosis treatment in the Netherlands: rates, risk factors and trends in the period 1993-1997. Eur Respir J. 2000;16(2):209-13. http://dx.doi.org/10.1034/j.13993003.2000.16b05.x. PMid:10968493.

15. Lefebvre N, Falzon D. Risk factors for death among tuberculosis cases: analysis of European surveillance data. Eur Respir J. 2008;31(6):1256-6o. http://dx.doi. org/10.1183/09031936.00131107. PMid:18515556.

16. Ditah IC, Reacher M, Palmer C, Watson JM, Innes J, Kruijshaar $\mathrm{ME}$, et al. Monitoring tuberculosis treatment outcome: analysis of national surveillance data from a clinical perspective. Thorax. 2008;63(5):440-6. http://dx.doi.org/10.1136/ thx.2006.073916. PMid:17615085.

17. Tattevin P, Che D, Fraisse P, Gatey C, Guichard C, Antoine D, et al. Factors associated with patient and health care system delay in the diagnosis of tuberculosis in France. Int J Tuberc Lung Dis. 2012;16(4):510-5. http://dx.doi.org/10.5588/ ijtld.11.0420. PMid:22325560.

18. Millett ER, Noel D, Mangtani P, Abubakar I, Kruijshaar ME. Factors associated with being lost to follow-up before completing tuberculosis treatment: analysis of surveillance data. Epidemiol Infect. 2012 Jul 30;1-9. http://dx.doi. org/10.1017/S095026881200163X. PMid:22846385.

19. Aerts A, Hauer B, Wanlin M, Veen J. Tuberculosis and tuberculosis control in European prisons. Int J Tuberc Lung Dis. 2006;10(11):1215-23. PMid:17131779.

20. Cochet $A$, Isnard $H$. Tuberculose dans les maisons d'arrêt en Ile-de-France. Enquête prospective, 1er juillet 2005-30 juin 2006. [Tuberculosis in prisons in the Paris area, A prospective study: 1 July 2005-30 June 2006]. Bull Epidemiol Hebd.
2008;(2):12-4. French. Available from: http://opac.invs.sante. $\mathrm{fr} /$ doc_num.php?explnum_id=3441

21. Baussano I, Williams BG, Nunn P, Beggiato M, Fedeli U, Scano F. Tuberculosis incidence in prisons: a systematic review. PLoS Med. 2010;7(12):e1000381. http://dx.doi.org/10.1371/journal. pmed.1000381. PMid:21203587 PMCid:3006353.

22. EuroTB (InVS/KNCV), National coordinators for tuberculosis surveillance in the WHO European Region. Surveillance of tuberculosis in Europe. Report on tuberculosis cases notified in 2002 . Saint-Maurice: Institut de veille sanitaire, 2004. Available from: http://www.ecdc.europa.eu/en/publications/ Publications/SUR_TB_EuroTB_Annual_report_2002.pdf

23. Hauer B, Brodhun B, Altmann D, Fiebig L, Loddenkemper R, Haas W. Tuberculosis in the elderly in Germany. Eur Respir J. 2011;38(2):467-70. http://dx.doi. org/10.1183/09031936.00199910. PMid:21804163. 